Meta

Journal des traducteurs

Translators' Journal

\title{
When Idioti (Idiotic) Becomes "Fluffy": Translation Students and the Avoidance of Target-language Cognates
}

\section{Brenda Malkiel}

Volume 54, numéro 2, juin 2009

URI : https://id.erudit.org/iderudit/037683ar

DOI : https://doi.org/10.7202/037683ar

Aller au sommaire du numéro

Éditeur(s)

Les Presses de l'Université de Montréal

ISSN

0026-0452 (imprimé)

1492-1421 (numérique)

Découvrir la revue

Citer cette note

Malkiel, B. (2009). When Idioti (Idiotic) Becomes "Fluffy": Translation Students and the Avoidance of Target-language Cognates. Meta, 54(2), 309-325.

https://doi.org/10.7202/037683ar

\section{Résumé de l'article}

La traduction des vrais et des faux amis n'est ni simple ni évidente. Un mot paraissant être un vrai ami pouvant se révéler un faux ami et le rapport existant entre un vrai et un faux ami étant parfois flou, les traducteurs et les étudiants en traduction tentent de limiter les risques et recherchent des solutions de traductions sans avoir recours aux vrais amis, même lorsque leur usage va de soi. La présente étude cherche, d'une part, à confirmer que les étudiants évitent l'emploi de vrais amis même lorsqu'ils seraient judicieux et appropriés et, d'autre part, à explorer la possibilité que ce phénomène serait lié à la crainte de l'utilisation de faux amis. Les résultats confirment que les étudiants tendent à éviter les vrais amis et que le degré de pertinence quant à l'utilisation des vrais amis est corrélé à celui qui est observé dans le cas des faux amis. 


\title{
ÉTUDES ET PROSPECTIVES
}

\section{When Idioti (Idiotic) Becomes "Fluffy": \\ Translation Students and the Avoidance of Target-language Cognates}

\author{
BRENDA MALKIEL \\ Bar-Ilan University, Ramat-Gan, Israel \\ brendamalkiel@gmail.com
}

\begin{abstract}
RÉSUMÉ
La traduction des vrais et des faux amis n'est ni simple ni évidente. Un mot paraissant être un vrai ami pouvant se révéler un faux ami et le rapport existant entre un vrai et un faux ami étant parfois flou, les traducteurs et les étudiants en traduction tentent de limiter les risques et recherchent des solutions de traductions sans avoir recours aux vrais amis, même lorsque leur usage va de soi. La présente étude cherche, d'une part, à confirmer que les étudiants évitent l'emploi de vrais amis même lorsqu'ils seraient judicieux et appropriés et, d'autre part, à explorer la possibilité que ce phénomène serait lié à la crainte de l'utilisation de faux amis. Les résultats confirment que les étudiants tendent à éviter les vrais amis et que le degré de pertinence quant à l'utilisation des vrais amis est corrélé à celui qui est observé dans le cas des faux amis.
\end{abstract}

\begin{abstract}
Cognate translation is neither a simple nor a straightforward matter. Given the risk that a word that appears to be a true cognate may actually be a false cognate, and given the sometimes fuzzy boundary between true and false cognates, translators and translation students have been shown to "play it safe" by casting around for noncognate translations for true cognates, rather than choose the obvious cognate translation. Here we ask whether translation students avoid cognate translations even when the target-language cognate is both accurate and appropriate and whether this phenomenon is related to fear of false friends. The findings indicate that translation students do seek out noncognate translations and that performance on true cognates correlates with performance on false cognates.
\end{abstract}

\section{MOTS-CLÉS/KEYWORDS}

vrais amis, faux amis, étudiants en traduction

true cognates, false cognates, translation students

\section{Introduction}

The transition from amateur to professional translation entails numerous changes in both process and product. As a rule, beginning translators will adopt a linguistically rather than a communicatively oriented strategy (Tirkkonen-Condit 1996: 252); cleave to the wording of the source text (Bastin 2000: 239); experience difficulty with lexicalization (Shlesinger 1992); and create texts with a source-based distribution of 
explicit cohesive markers (Blum-Kulka 1986: 20). With experience, changes occur in these areas as well as, inter alia, the degree of control over interference (Presas 2000: 27); sensitivity to the target audience (Fraser 1993: 330); and the use of reference works (Jääskeläinen 1989a; Jensen 1999: 113).

With growing professionalism, some aspects of the translation process become automatized (Börsch 1986: 207; Toury 1992: 69), and therefore require less effort; this, however, is counterbalanced by a heightened sensitivity to potential translational problems (Jääskeläinen and Tirkkonen-Condit 1991: 105) and ever-higher standards (Gerloff 1988: ix-x). As they make their way through their studies, translation students adopt a new attitude towards the act of translation itself, characterized by a growing appreciation of the complexity of the translation process (Krouglov 1996: 84).

One area in which this new attitude is expressed is the translation of cognates. ${ }^{1}$ In the laboratory, bilinguals translate cognates more quickly than noncognates (Murray 1986; de Groot et al. 1994; Kroll and Stewart 1994), and more accurately as well (Sánchez-Casas et al. 1992; Hancin-Bhatt and Nagy 1994; de Groot and Poot 1997). Professional translators, however, attest to the difficulty attendant in translating cognates, and research in Translation Studies has shown that translation students and professional translators do not automatically translate a cognate with a cognate.

\section{The translation of cognates}

Crystal (1997: 67) defines "cognate" as "a language or linguistic form which is historically derived from the same source as another language/form." While some linguists espouse the traditional etymologically based definition of a cognate, Carroll (1992: 102) maintains that from the psycholinguistic perspective, the shared history of cognates is irrelevant: "Words do not wear their historical origins on their sleeves. Etymological information is not part of the information normally encoded in the (linguistic) lexical entry of a word."

Cognates are thought to fall into two categories - true cognates, which share both sound and meaning, and false cognates, which share sound but not meaning. The distinction between true and false cognates is, however, often blurred. According to Browne (1982: 5), cognates really fall along a continuum, from "vrais amis," which have almost complete overlap, to "faux amis" with none.

The translation of false cognates is a "traditionally notorious aspect of translation” (Sabaté-Carrové and Chesňevar 1998: 58). There is a risk that the translator will mistake a false cognate for a true one, and thus make a serious (and embarrassing) error. Although especially beguiling to novice translators (Bastin 2000: 236; Presas 2000: 26), false cognates can be problematic for anyone (Topalova 1996: 215). False cognates are not limited to any particular field, and even occur in technical language (Newmark 1996: 57).

Given the risk that a word that appears to be a true cognate may actually be a false cognate, and given the sometimes fuzzy boundary between true and false cognates, translators have been shown to "play it safe" by casting around for noncognate translations for true cognates, rather than choose the obvious cognate translation (Kussmaul 1995: 17-18; Kussmaul and Tirkkonen-Condit 1995: 187; Gile 1995: 218). Interpreters as well are often leery of cognates (Gernsbacher and Shlesinger 1997: 137; de Bot 2000: 77-8; Shlesinger 2000: 115). 
The underlying assumption in these studies is that the source language (SL) cognate has a ready-made translation solution in the target language (TL). When translators or interpreters encounter a cognate, the first option to come to mind is the ready-made solution, the TL cognate; should it be found lacking, for whatever reason, they will then search for other options. Put differently, the obvious translation is the cognate; the noncognate solution is selected only after the cognate has been considered and rejected.

Apart from the risk of mistaking a false cognate for a true cognate, there can be compelling reasons for not choosing to translate a cognate with a cognate. Two languages rarely have exact lexical matches (Seleskovitch 1978: 338; de Groot and Comijs 1995: 470), so rarely that Rabadán (1991: 39) maintains that "the chances of finding perfectly symmetrical correspondents depend on sheer coincidence." Even seemingly reliable translation equivalents - cognates being a case in point - can have a much more complicated relationship than meets the eye (Partington 1995: 102).

According to Rabassa (1989: 4), the translator working from Spanish into English "must know that tigre can mean 'tiger' in English only when the creature is a denizen of the Old World. When a tigre turns up in Venezuela, it must perforce be rendered as 'jaguar'." Viaggio (1991: 176) argues that when "To be or not to be, that is the question” is translated into Spanish, the translator should preferably spurn the obvious choice, the cognate cuestión, in favor of another English-Spanish cognate, dilema.

Rabassa (1989) is concerned that the referent of the original Spanish text be accurately rendered in the English translation, and Viaggio (1991) is interested in reproducing the semantics and rhythm of the original. The translation of cognates is complicated by other considerations as well, including differences in frequency (Nagy et al. 1992: 2; Meara 1993: 284), varying degrees of polysemy (Viberg 1999), register differences (Alter 2002: 11), dissimilar metaphorical extensions (Chamizo Domínguez and Nerlich 2002: 1839), syntactical restrictions (Fusco 1990: 93), gridding differences (Aitchison 1996: 18; Séguinot 1997: 115), and the wealth of associations evoked by the SL or TL cognate (Wallerstein 1996: 114-115; Santos Maldonado 1997: 94).

The translation of ST cognates borrowed from the target language is particularly fraught. Loan words lend a certain sophistication or prestige to the text (Baker 1992: 25; Barbe 1997: 147), and this quality is, of course, lost when the loan word is translated back into the lending language. Eco (2001: 47) speaks for the professional translator when he writes: "I feel that in a translation from French it is necessary to avoid using Gallicisms, just as it is necessary to avoid Anglicisms in a translation from English."

In short, the translation of cognates is neither simple not straightforward. While sometimes the translator might spurn the TL cognate out of fear of false cognates, other times the decision to search for a noncognate synonym is based on bona fide differences between the source and target languages. Two studies which address cognate translation - Gerloff (1988) and Séguinot (1990) - indicate that translation students and translators do not adopt a thought-through policy towards cognates, but instead operate on a case-by-case basis.

Gerloff (1988) compares the approach of language students, bilinguals, and professionals to three cognates in her French text. While three of the four translators and two of the four bilinguals translated diversifiée with the cognate "diversified," 
only one of the students did. The situation was very different regarding fausses, where "false" was chosen by three of the four students but none of the bilinguals or translators. A third cognate generated more variation than either diversifiée or fausses. Séguinot (1990: 72) found that translation of cognates was subject to change over time, and not necessarily for the better. Regarding one subject, she remarks: "The Anglophone student translates words like particulier and bistro appropriately in first year, but translates incorrectly, clearly influenced by the words in the source text in her last year."

While the texts administered by Gerloff and Séguinot contained cognates, cognate translation is a secondary concern for these scholars. The present study is unusual in that the translation of cognates is its primary focus. We ask two questions: Do translation students seek out noncognate solutions for ST cognates? Is there a relationship between the indirect translation of true cognates and awareness of false cognates?

\section{Method}

\subsection{Subjects}

The subjects $(\mathrm{N}=15)$ were translation students at Beit Berl College in Israel. Beit Berl offers a two-year translation program, with 10 academic hours of instruction per week and 27 weeks of classes per year. At the time of administration, the students were midway through the program, having completed one year (270 hours) of studies.

When they were accepted to the program, most of the subjects held a B.A. and some an M.A.; the others were high-school graduates with some higher education but no university degree. The subjects ranged in age from their mid-twenties to their mid-sixties. Eleven were female and four male. All were native English speakers, here translating from Hebrew into their mother tongue. The students did not receive course credit or any financial remuneration for their participation.

\subsection{Materials}

Once we jettison the etymological definition of a cognate in favor of a psycholinguistic one, we must then determine which words we consider to be cognates, a complicated task in its own right. $^{2}$ Although researchers are divided as to how closely two words must resemble each another in order to be considered cognate (Dijkstra et al. 1999: 500), the general consensus is that cognates "share aspects of both form and meaning across languages" (Kroll and de Groot 1977: 173).

With regard to Hebrew and English, the languages of this study, so many Hebrew-English cognates began life in English that Gollan et al. (1997: 1123) maintain they should more accurately be called loan words. Although the new Hebrew word has a distinct similarity to its English cognate, it will have typical Hebrew phonology, morphology, and orthography, e.g. the English "television/s" becomes the Hebrew televizya/ot and the English "modern" becomes the Hebrew moderni/t/im/ot. We have employed the criterion of phonological similarity in determining cognate status. 
This experiment is based on a 340-word Hebrew text containing 44 true and 12 false cognates. However, since one of the true cognates appears twice, once in the first paragraph and once in the last, for purposes of data analysis we considered the text to have 45 true cognates. Because the vast majority of Hebrew-English cognates are nouns and adjectives, the cognates in the text are all either nouns or adjectives.

This text was first written in English and then translated into Hebrew. All of the cognates in the Hebrew text were present in cognate form in the original English; therefore, when this text was backtranslated into English by the subjects, each Hebrew cognate could be translated accurately and appropriately using the English cognate. The significance of this feature is discussed below.

Apart from the presence of the cognates, we had three other guidelines in composing the text: (a) it should not be obvious that we were interested in translation of the cognates; (b) for purposes of face validity, it should closely approximate an authentic Hebrew text; and (c) it should take the students no more than two hours to translate.

To distract the subjects from the presence of cognates, the text contains numerous references to Israeli culture, e.g., two typical Middle Eastern foods, the nowobsolete Israeli phone token, and two well-known Israeli authors. In light of the fact that the translation brief instructs the subjects to translate the text as if it were to be published in the New York Times, ${ }^{3}$ the culturally based references require the translator to decide how much information must be added to best serve the needs of the target audience. It was our expectation that the cultural references would suffice to distract the subjects from the cognates in the text, and indeed in discussions of the text conducted after the experiment, not one subject commented on the presence of the cognates.

As for the second criterion, that the text should sound authentic, the text has the content and structure of a typical Op-Ed published in the Hebrew press. It was examined by three native Hebrew speakers who pronounced it acceptable. Third, we estimated that this text would take between one and two hours to translate. Because there is evidence that asking a subject to translate an extract rather than a whole text can give rise to problems in both comprehension and translation (Tirkkonen-Condit 1986: 95-96), we chose to have the subjects translate one text in its entirety rather than short excerpts from several texts.

\subsection{Procedure}

\subsubsection{Administration}

Ideally, translation tests should replicate the normal working environment of the translator (Séguinot 1997: 106). Since these translation students typically work at home on a computer and have free access to reference works, the subjects were asked to translate the text on their home computers and had permission to consult any printed or on-line resources of their choice.

The subjects received the Hebrew text by e-mail with instructions to submit their translations two weeks later. At that time, the translations were collected, and the students were instructed to delete their initial translation from their computers, and to translate the text again from scratch. This time too they were given two weeks to complete the translation. There was no way to guarantee that the subjects did not consult their first translation when they produced their second. 
A comparison of the translations from the first and second administrations (below, Administration A and Administration B, respectively) showed that fourteen of the fifteen subjects had produced a second translation that differed both in syntax and in word choice from their first version. One subject, however, submitted a second version that was almost identical to his first. Because we considered the two administrations to be an important feature of our experimental design, we disregarded both of the translations submitted by this subject. All of our data analysis was then based on the twenty-eight translations submitted by the other fourteen subjects.

We coded both sets of data, determining whether the cognates in the ST were translated in cognate or noncognate form. Once we reject the etymological definition of a cognate in favor of a psycholinguistic one, we are forced to formulate a policy for determining which words we consider as cognates. In coding the data, we observed the following three principles:

(1) Each of the true cognates in the Hebrew text has a ready-made equivalent in English. If the subject chose a word that was similar but not identical to the closest English equivalent, e.g. "reformation" instead of "reform" for the Hebrew reforma, we considered the translation to be noncognate. The underlying assumption here is that the first solution that comes to mind is the one closest to the Hebrew, and that any other translation - even an etymologically related one - is evidence of further processing, i.e., evidence that the ready-made equivalent was considered and rejected.

(2) When the subject chose to translate a true cognate into a cognate form but changed the part of speech, we considered the translation to be a cognate. Translation students are encouraged to make their text conform to the norms of TL syntax and usage, and this often includes changing parts of speech.

(3) To correctly translate a false cognate, the subject must translate the word by meaning and not by sound. In many cases, the subjects translated the false cognate by sound, but then added a word or words to the translation, e.g., the Hebrew academai (college graduate) became the English "with academic training." When this happened, we considered the translation to be correct, based on the rationale that the additional words are evidence that the subject recognized that the Hebrew word was a false cognate.

One of the words in the text, chips (French fries), is a true cognate in British English and a false cognate in American English. Because the brief instructs the students to translate the text as if it were to appear in the New York Times, an American newspaper, "chips" was considered a false cognate.

\subsubsection{Reliability and validity}

According to Campbell (1998), the traditional methods of measuring reliability are problematic for text translation. Although Campbell's remarks are addressed to accreditation testing, his arguments are equally compelling with regard to empirical research in translation. The equivalent-forms method is flawed since by definition no texts are truly equivalent; test-retest opens the door to the possibility that the subject will have gained experience in the interim between the two tests, or that in the second administration s/he will apply lessons learned during the first; split-halves require that the text be divided into arbitrary units, with the easier chunks of text rendering the test highly redundant, and the numerous target versions making assessment very difficult. Campbell concludes that "the only recourse is to judgements of inter-marker reliability" (1998: 172). 
With Campbell's comments in mind, we felt it especially important to have an experimental design which would guarantee high inter-rater reliability. Our interest in cognate status, rather than in less-easily-quantified qualities such as syntax or equivalence, allowed us to design a simple and reliable rating process. Three HebrewEnglish bilinguals were asked to perform two tasks: to pick out the English translations of the Hebrew cognates from the translated texts and to determine whether the cognates were translated in cognate or noncognate form.

We measured inter-rater reliability by having three translations coded by each of three raters. The three translations were chosen to represent the range of translations received: One had the most cognates translated in noncognate form, one had the fewest, and the third was about average. Each of the raters was given a copy of the three translations, an instruction sheet setting out the rating procedure, and three copies of the rating forms. After the raters had carefully read the instruction sheet, they were instructed in the principles we had established for determining cognate status, as set out above.

Since the Hebrew text contains 57 true and false cognates, the two rating forms together have 57 items, and the six rating forms (two per subject for each of three subjects) contain a total of 171 items. We considered 171 items rated by three different raters sufficient to calculate inter-rater reliability. In 166 cases, all three raters identified the same English word or words as the translation of the Hebrew cognate and all three entered the English word or words in the same column of the rating form. Inter-rater reliability is therefore $97 \%$.

Campbell (1998: 173-175) is as pessimistic about validity as he is about reliability, and finds problems with concurrent, predictive, ecological, and construct validity. To summarize his arguments: concurrent validity is difficult to judge; predictive validity is a factor of the test conditions and the specific texts; ecological validity presupposes that the texts translated will provide a global view of the candidate's ability, which they very well might not; and construct validity is problematic because translation tests are not based on an explicit theory. Campbell maintains that translation tests will have face validity provided they meet two conditions: the environment is similar to the subject's usual working environment and the texts are representative of those the subject generally translates. Both are true in our case.

As set out in Procedure, our experimental design calls for two separate administrations of the same text. Our methodology differs from the conventional test-retest in that we are not interested in assessing ability but in examining which textual elements remain from the first administration to the second and which change.

\section{Findings}

\subsection{Do translation students seek out noncognate solutions for ST cognates?}

The data below are analyzed by subject, by cognate, and by administration.

\subsubsection{By subject}

Thirteen of the fourteen subjects indirectly translated at least one of the 45 true cognates present in the Hebrew text. Table 1 presents the number of noncognate equivalents produced by the subjects in each administration. 
TABLE 1

True cognates indirectly translated, by subject

\begin{tabular}{|l|c|c|c|}
\hline Subject & $\begin{array}{c}\text { Administration } \\
\text { A }\end{array}$ & $\begin{array}{c}\text { Administration } \\
\text { B }\end{array}$ & $\begin{array}{c}\text { Administrations } \\
\text { A + B }\end{array}$ \\
\hline A & 13 & 12 & 25 \\
\hline B & 13 & 11 & 24 \\
\hline C & 9 & 13 & 19 \\
\hline D & 11 & 8 & 17 \\
\hline E & 6 & 7 & 12 \\
\hline F & 5 & 5 & 8 \\
\hline G & 3 & 4 & 8 \\
\hline H & 4 & 5 & 7 \\
\hline I & 2 & 4 & 4 \\
\hline J & 1 & 3 & 4 \\
\hline K & 1 & 3 & 2 \\
\hline L & 1 & 1 & 0 \\
\hline M & 1 & 0 & $\mathbf{1 5 7}$ \\
\hline N & 0 & $\mathbf{8 7}$ & $\mathbf{5 . 6}$ \\
\hline Total & $\mathbf{7 0}$ & $\mathbf{6 . 2}$ & $\mathbf{8 . 6}$ \\
\hline Mean & $\mathbf{5}$ & $\mathbf{4 . 2}$ & \\
\hline SD & $\mathbf{4 . 7}$ & & \\
\hline
\end{tabular}

While every subject but one translated at least one cognate into a noncognate form, there is a great deal of variation in the number of noncognate solutions that were produced. Although the subjects do not fall into clear-cut groups, the data suggest that some students seek out noncognate solutions, others do not, and members of a third group generally choose cognate solutions but will on occasion opt for the noncognate. It should be noted, however, that even those students who most often indirectly translated the cognate produced almost three times more cognate solutions than noncognate solutions in their translations.

\subsubsection{By cognate}

When we analyze the data by cognate rather than by subject, we find that 34 of the 45 true cognates in the Hebrew text were translated into a noncognate form by at least one subject in one administration. Put differently, three-quarters of the true cognates in the text generated one or more noncognate equivalents.

TABLE 2

True cognates and their noncognate translations, by cognate (in order of appearance in the text)

\begin{tabular}{|l|l|l|}
\hline $\begin{array}{l}\text { English equivalent } \\
\text { for the Hebrew cognate }\end{array}$ & \multicolumn{1}{|c|}{ Administration A } & \multicolumn{1}{c|}{ Administration B } \\
\hline Anecdote & Story (2), instance, tale & $\begin{array}{l}\text { Story (3), example (2), tale } \\
\text { (2), account }\end{array}$ \\
\hline Student & - & - \\
\hline Semester & Term & Term (2) \\
\hline Professors & Lecturers (2) & Lecturers, teacher \\
\hline Projects & - & Nuts to crack \\
\hline Reform & Change & Improvement, reformation \\
\hline Elite (n.) & $\begin{array}{l}\text { Upper-classes (2), privileged, } \\
\text { wealthy, well-to-do }\end{array}$ & $\begin{array}{l}\text { Rich (2), affluent, economi- } \\
\text { cally advantaged, privileged, } \\
\text { upper classes, wealthy }\end{array}$ \\
\hline
\end{tabular}




\begin{tabular}{|c|c|c|}
\hline Exclusive & Choice, expensive, up-market & Well-off \\
\hline Television & TV (3) & - \\
\hline Digital & - & - \\
\hline Norm & Usually, there is barely & Average, standard, usually \\
\hline Media & Multimedia (2) & Multimedia (3) \\
\hline Trivial & $\begin{array}{l}\text { Unimportant (2), insignifi- } \\
\text { cant }\end{array}$ & $\begin{array}{l}\text { Inconsequential, minor, } \\
\text { insignificant }\end{array}$ \\
\hline Campus & School grounds & School grounds (2) \\
\hline Theory & Conventional wisdom & Conventional wisdom \\
\hline Dramatic & - & Significant (2) \\
\hline Absurd & - & Incomprehensible \\
\hline Technological & - & - \\
\hline Optimal & $\begin{array}{l}\text { Ideal (adj.) (2), ideal (n.) (2), } \\
\text { ideally (2) }\end{array}$ & $\begin{array}{l}\text { Ideal (adj.) (2), should be the } \\
\text { case (2), ideally, more } \\
\text { beneficial, should be true, } \\
\text { what we are striving for }\end{array}$ \\
\hline Ideology & - & - \\
\hline Patriotism & Identity & $\begin{array}{l}\text { National identity, national- } \\
\text { ism }\end{array}$ \\
\hline Pragmatic & Practical (3) & Practical \\
\hline Relevant & - & - \\
\hline Dynamic (n.) & $\begin{array}{l}\text { Attitude, force, mode, school } \\
\text { of thought, trend }\end{array}$ & $\begin{array}{l}\text { Approach (2), attitude, force, } \\
\text { way of thinking }\end{array}$ \\
\hline University & College (3) & College (2) \\
\hline Statistically & Significant, steep & Increasingly, significant \\
\hline Practical & - & - \\
\hline Philosophy & - & - \\
\hline Model & - & Approach \\
\hline Ideal & - & Principles \\
\hline Classical & - & - \\
\hline Apropos & $\begin{array}{l}\text { As far as, as regards, like } \\
\text { that, speaking of, talking of, } \\
\text { while on the subject of }\end{array}$ & $\begin{array}{l}\text { Speaking of (2), as far as, just } \\
\text { as, not only, talking about, } \\
\text { talking of, while on the } \\
\text { subject of }\end{array}$ \\
\hline Drastically & $\begin{array}{l}\text { Acute, dramatically, far less, } \\
\text { much less, seriously }\end{array}$ & $\begin{array}{l}\text { Almost completely, dramati- } \\
\text { cally }\end{array}$ \\
\hline Popularity & Ubiquitous & Fashion, prominent \\
\hline Ironic & Cynical & - \\
\hline Tragic & Sad, strange & Cynical, sad \\
\hline Diet & - & Plate \\
\hline Hamburger & - & Big Mac Happy Meal \\
\hline Milkshake & - & - \\
\hline T-shirt & - & - \\
\hline Humor & Wit & Writings \\
\hline Idiotic & $\begin{array}{l}\text { Lightweight, mindless, } \\
\text { ridiculous, trashy }\end{array}$ & $\begin{array}{l}\text { Silly (2), fluffy, inane, } \\
\text { mindless, ridiculous, trashy }\end{array}$ \\
\hline Political & - & - \\
\hline Students & - & $\begin{array}{l}\text { Pupils and students, } \\
\text { university students }\end{array}$ \\
\hline Diploma & Degree (2) & Degree \\
\hline Total noncognate solutions & 70 & 87 \\
\hline
\end{tabular}

The Hebrew text contained 45 true cognates, and the subjects produced a total of 157 noncognate solutions out of a possible 630. The majority of cognates, then, were translated directly, which dovetails with the fact that every subject translated more cognates directly than indirectly. Nonetheless, the avoidance of cognate 
equivalents is not an isolated phenomenon, limited to one subject or one cognate: 34 out of 45 cognates were indirectly translated at least once.

Like the by-subject analysis, the by-cognate analysis shows considerable variation. In the two administrations, the Hebrew for "apropos" and "optimal" were translated in noncognate form a total of fourteen times each, both in a number of different ways, while other cognates generated no noncognate equivalents whatsoever.

\subsubsection{By administration}

Table 3, below, presents the noncognate solutions proposed by each subject. Words that were translated in cognate form in one administration and in noncognate form in the other are underlined. The 20 words that were translated in noncognate form in both administrations, but differently, are italicized for Administration B.

TABLE 3

True cognates in noncognate form, by subject

\begin{tabular}{|c|c|c|}
\hline Subject & $\begin{array}{l}\text { Administration A: True cognates in } \\
\text { noncognate form }\end{array}$ & $\begin{array}{l}\text { Administration B: True cognates in } \\
\text { noncognate form }\end{array}$ \\
\hline A & $\begin{array}{l}\text { Instance, upper classes, expensive, school } \\
\text { grounds, ideal, identity, trend, college, as } \\
\text { far as, far less, ubiquitous, cynical, sad }\end{array}$ & $\begin{array}{l}\text { Example, economically advantaged, well- } \\
\text { off, school grounds, significant, ideal, } \\
\text { national identity, college, approach, not } \\
\text { only, prominent, cynical }\end{array}$ \\
\hline B & $\begin{array}{l}\text { Term, lecturers, upper-classes, usually, } \\
\text { multi-media, unimportant, ideally, } \\
\text { practical, attitude, steep, as regards, } \\
\text { much less, lightweight }\end{array}$ & $\begin{array}{l}\text { Term, teacher, improvement, rich, multi- } \\
\text { media, minor, ideally, attitude, talking } \\
\text { about, almost completely, silly }\end{array}$ \\
\hline $\mathrm{C}$ & $\begin{array}{l}\text { Change, multimedia, insignificant, ideal, } \\
\text { practical, school of thought, college, } \\
\text { significant, seriously }\end{array}$ & $\begin{array}{l}\text { Story, term, rich, usually, insignificant, } \\
\text { school grounds, significant, ideal, } \\
\text { practical, way of thinking, increasingly, } \\
\underline{\text { writings, university students }}\end{array}$ \\
\hline $\mathrm{D}$ & $\begin{array}{l}\text { Story, lecturers, well-to-do, upmarket, } \\
\text { TV, there is barely, conventional wisdom, } \\
\text { colleges, talking of, strange, mindless }\end{array}$ & $\begin{array}{l}\text { Story, lecturers, upper classes, standard, } \\
\text { conventional wisdom, talking of, } \\
\text { mindless, pupils and students }\end{array}$ \\
\hline E & Choice, ideal, mode, like that, acute, wit & $\begin{array}{l}\text { Nuts to crack, reformation, average, } \\
\text { inconsequential, more beneficial, } \\
\text { approach, principles, just as, plate, Big } \\
\text { Mac Happy Meal, inane }\end{array}$ \\
\hline $\mathrm{F}$ & $\begin{array}{l}\text { TVs, force, speaking of, dramatically, } \\
\text { ridiculous }\end{array}$ & $\begin{array}{l}\text { Account, affluent, incomprehensible, } \\
\text { force, speaking of, dramatically, } \\
\text { ridiculous }\end{array}$ \\
\hline G & Tale, privileged, trashy & Tale, privileged, multi-media, sad, trashy \\
\hline $\mathrm{H}$ & $\underline{\text { TVs }}$, unimportant, ideally, practical & $\begin{array}{l}\text { Example, should be the case, approach, } \\
\text { fluffy }\end{array}$ \\
\hline I & Story, degree & $\begin{array}{l}\text { Tale, multi-media, should be true, } \\
\text { nationalism, colleges }\end{array}$ \\
\hline J & Ideal & $\begin{array}{l}\text { Story, What we are striving for, as far as, } \\
\text { degree }\end{array}$ \\
\hline $\mathrm{K}$ & While on the subject of & $\begin{array}{l}\text { Significant, while on the subject of, } \\
\underline{\text { fashion }}\end{array}$ \\
\hline
\end{tabular}




\begin{tabular}{|l|l|l|}
\hline L & Wealthy & Wealthy, speaking of, silly \\
\hline $\mathrm{M}$ & Degree & Should be the case \\
\hline $\mathrm{N}$ & - & - \\
\hline Total & $\mathbf{7 0}$ & $\mathbf{8 7}$ \\
\hline
\end{tabular}

Underlined: Words translated in cognate form in one administration and in noncognate form in the other. Italics (Administration B only): Words translated with a different noncognate synonym on each administration.

The subjects were more likely to choose noncognate synonyms when they translated the ST for the second time. The first set of translations contains an average of 5 noncognate equivalents, and the second set an average of 6.2. Along with this, 26 different cognates were translated at least once in noncognate form on the first administration and 32 on the second. There were also changes in how the subjects chose to translate the cognates. In twenty cases a subject proposed one noncognate solution for a certain Hebrew cognate in Administration A and a different noncognate solution in Administration B. Like other words, cognates can be and are translated in any number of different ways.

As presented above, it is a given that there are few perfect lexical matches, even for cognates. We would therefore expect the translator to look for noncognate alternatives when the cognate solution was inappropriate because of register, gridding, collocational restrictions, or any other reason. Our subjects, however, searched for noncognate equivalents even when the English cognate would have been perfectly acceptable. As discussed in the Materials section, all 45 true cognates in the Hebrew text could correctly and appropriately be translated into English in cognate form. Our subjects rejected the ready-made, correct cognate solution in favor of a variety of noncognate translations.

Not only did they reject the ready-made solution, almost across the board their noncognate equivalents were less accurate than the cognate would have been. For the Hebrew tragi (tragic), for example, the subjects proposed three noncognate translations - sad, strange, and cynical - none of which completely captures the meaning of "tragic." There are a few exceptions to this rule, where the noncognate solutions have a denotation very similar to that of the cognate, such as "degree" for diploma (diploma). In certain isolated cases, the noncognate translations add a flavor to the text that the cognate would not have, e.g., one subject translated hamburger (hamburger) as "Big Mac Happy Meal."

\subsection{Is there a relationship between the indirect translation of true cognates and awareness of false cognates?}

It has been suggested in the literature that translation students and professional translators avoid the direct translation of the cognate out of fear of false cognates. Indeed, our data indicates that those subjects who avoided the direct translation of true cognates made fewer errors on false cognates than those subjects who generally replaced a cognate with a cognate. Table 4 compares the number of times each subject indirectly translated true cognates with the number of times this subject mistranslated false cognates. 
TABLE 4

Comparison of true cognates translated in noncognate form with mistranslations of false cognates, by subject and administration

\begin{tabular}{|c|c|c|c|c|}
\hline Subject & $\begin{array}{c}\text { Noncognate } \\
\text { solutions: } \\
\text { Administration A } \\
\end{array}$ & $\begin{array}{l}\text { Mistranslated false } \\
\text { cognates: } \\
\text { Administration A }\end{array}$ & $\begin{array}{c}\text { Noncognate } \\
\text { solutions: } \\
\text { Administration B } \\
\end{array}$ & $\begin{array}{c}\text { Mistranslated false } \\
\text { cognates: } \\
\text { Administration B } \\
\end{array}$ \\
\hline A & 13 & 1 & 12 & 1 \\
\hline B & 13 & 3 & 11 & 2 \\
\hline $\mathrm{C}$ & 9 & 0 & 13 & 0 \\
\hline $\mathrm{D}$ & 11 & 1 & 8 & 2 \\
\hline $\mathrm{E}$ & 6 & 0 & 11 & 0 \\
\hline $\mathrm{F}$ & 5 & 3 & 7 & 2 \\
\hline G & 3 & 3 & 5 & 2 \\
\hline $\mathrm{H}$ & 4 & 5 & 4 & 4 \\
\hline I & 2 & 2 & 5 & 1 \\
\hline $\mathrm{J}$ & 1 & 5 & 4 & 4 \\
\hline $\mathrm{K}$ & 1 & 5 & 3 & 5 \\
\hline $\mathrm{L}$ & 1 & 4 & 3 & 4 \\
\hline $\mathrm{M}$ & 1 & 3 & 1 & 4 \\
\hline $\mathrm{N}$ & 0 & 5 & 0 & 4 \\
\hline Total & 70 & 40 & 87 & 35 \\
\hline $\begin{array}{l}\text { Pearson's } \\
\text { correlation }\end{array}$ & \multicolumn{2}{|c|}{-0.6462} & \multicolumn{2}{|c|}{-0.8385} \\
\hline
\end{tabular}

The Pearson's correlation for the first administration is -0.6462 ; the correlation for the second administration is a stronger -0.8385; and the correlation for the two administrations together is -0.7357 . The inverse relationship between the number of noncognate solutions and the number of mistranslated false cognates is particularly marked in Administration B, when the subjects, familiar with the text, produced more noncognate translations of true cognates (87 as opposed to 70 ) and performed somewhat better on the false cognates ( 35 mistranslated false cognates as opposed to 40).

There is, then, a correlation between performance on false cognates and the use of noncognate forms. While this does not necessarily point to fear of false cognates, it does indicate that the subjects who are aware of the risk of false cognates and successfully translate false cognates by meaning rather than by sound are more likely to seek out noncognate translations for true cognates than are those students who mistranslate false cognates.

\subsection{Post hoc findings}

While it was not the purpose of this study to examine how the subjects handled false cognates, the findings in this regard merit special mention. Our data confirms that false cognates pose "significant obstacles" to the translator (Topalova 1996: 215). Twelve out of fourteen subjects mistranslated at least one false cognate on both administrations, and the majority mistranslated several.

Even though the subjects were aware that the Hebrew text contained false cognates - as evidenced by the fact that they correctly translated most of the false cognates in the text - few subjects were unable to ferret out and correctly translate all twelve false cognates. 


\section{Discussion}

Researchers argue that translation students and professional translators alike seek out noncognate equivalents for ST cognates, motivated, at least in part, by fear of false cognates. Our results confirm that translation students will at times reject the direct translation of the cognate in favor of a noncognate equivalent and that the subjects who made the most strenuous efforts to avoid cognate equivalents were also those who were the most successful at correctly translating false cognates. This said, there was a good deal of variation in the data - variation from subject to subject, cognate to cognate, and administration to administration.

Although we did not investigate what motivated these students to translate the cognate indirectly, based on the correlation between noncognate translations of true cognates and performance on false cognates, we see our results as potentially supporting the thesis put forth by Gile (1995), Kussmaul (1995), and Kussmaul and Tirkkonen-Condit (1995) that there is a relationship between the search for noncognate solutions and the fear of false cognates.

After having spent a year in the classroom, our subjects are well-enough versed in translation theory to know that the cognate translation is certainly not the only option, and not necessarily the best option. At the same time, they are not yet secure enough and professional enough to choose the cognate solution when it is indeed appropriate. We regard their performance here as support for Toury (1992: 68) and Livbjerg and Mees (1999: 145-146), among others, who maintain that translation students are plagued by insecurity. In most cases, the cognate translation would have been as good as (if not better than) the noncognate synonyms proposed by the translation students.

The data shows that translation students do avoid cognate translations - some students more than others - and that the avoidance of cognate translations correlates with performance on false cognates. We have not yet resolved the question of why translation students seek out noncognate synonyms when TL cognates are available. To do so will require the use of think-aloud protocols, Translog word-processing software, or interviews. From the present study, it seems likely that cognizance of the complexities of professional translation goes hand-in-hand with fear of false cognates. Anxious to produce the best possible translation and loath to mistake a false cognate for a true cognate, the translation student looks beyond the obvious cognate translation to noncognate synonyms. This is particularly true when the subjects are more familiar with the ST.

Cognates provide a reliable and easily quantifiable tool for future research. How translation students and professional translators choose to translate cognates can be seen as a reflection not of only their attitude towards cognates but of their attitude towards the entire enterprise of translation.

\section{ACKNOWLEDGEMENTS}

The author expresses her gratitude to Miriam Shlesinger (as always) and to Joel Walters.

\section{NOTES}

1. Below the term "cognate" refers to true cognates; false cognates are referred to as such. We speak of "direct translation" or "cognate solution" when the ST cognate is translated with a cognate in 
the TT and "indirect translation" or "noncognate solution" when the translator chooses a noncognate equivalent.

2. See, for example, Kroll and Stewart (1994) regarding Dutch-English cognates, Santos Maldonado (1997) regarding Spanish-English cognates, and Goodrich (1977) regarding Arabic-English false cognates.

3. For the role of the translation brief, see Fraser (2000: 53) and Jääskeläinen (1989b: 89). The presence of the brief is particularly important in this case, given that the text draws heavily on Israeli politics and culture.

\section{REFERENCES}

Aitchison, Jean (1996): Taming the Wilderness: Words in the Mental Lexicon. In: Gunilla Anderman and Margaret Rogers, eds. Words, Words, Words: The Translator and the Language Learner. Clevedon: Multilingual Matters, 15-26.

Alter, Robert (2002): The Sweet Cheat Well and Truly Gone. Times Literary Supplement 5195:11-12.

BAKer, Mona (1992): In Other Words: A Coursebook on Translation. London: Routledge.

BARBE, Katharina (1997): The Translation of Loans: Anglicisms in German. Perspectives: Studies in Translatology. 2(2):147-160.

Bastin, Georges (2000): Evaluating Beginners' Re-expression and Creativity: A Positive Approach. The Translator: Studies in Intercultural Communication. 6(2):231-245.

Blum-Kulka, Shoshana (1986): Shifts of Cohesion and Coherence in Translation. In: Juliane House and Shoshana Blum-Kulka, eds. Interlingual and Intercultural Communication: Discourse and Cognition in Translation and Second Language Acquisition Studies. Tübingen: Narr, 17-35.

BöRsch, Sabine (1986): Introspective Methods in Research on Interlingual and Intercultural Communication. In: Juliane House and Shoshana Blum-Kulka, eds. Interlingual and Intercultural Communication: Discourse and Cognition in Translation and Second Language Acquisition Studies. Tübingen: Narr, 195-209.

Browne, Robin Leslie (1982): Aural and Visual Recognition of Cognates and Their Implications for the Teaching of Cognate Languages. Unpublished doctoral dissertation. Cambridge: Harvard University.

Campbell, Stuart (1998): Translation into the Second Language. London: Longman.

CArroll, Susanne E. (1992): On Cognates. Second Language Research. 8(2):93-119.

Chamizo Domínguez, Pedro José and Nerlich, Brigitte (2002): False Friends: Their Origin and Semantics in Some Selected Languages. Journal of Pragmatics. 34:1833-1849.

Crystal, David (1997): Dictionary of Linguistics and Phonetics, $4^{\text {th }}$ ed., Oxford: Blackwell.

Dе Вот, Kees (2000): Simultaneous Interpreting as Language Production. In: Birgitta Englund Dimitrova and Kenneth Hyltenstam, eds., Language Processing and Simultaneous Interpreting, Amsterdam: John Benjamins, 65-88.

De Groot, Annette M.B. and Comijs, Hannie (1995): Translation Recognition and Translation Production: Comparing a New and an Old Tool in the Study of Bilingualism. Language Learning. 45(3):467-509.

De Groot, Annette M.B., Dannenburg, Lucia and Van Hell, Janet G. (1994): Forward and Backward Word Translation by Bilinguals. Journal of Memory and Language. 33:600-629.

De Groot, Annette M.B. and Poот, Rik (1997): Word Translation at Three Levels of Proficiency in a Second Language: The Ubiquitous Involvement of Conceptual Memory. Language Learning. 47(2):215-264.

Dijkstra, Ton, Grainger, Jonathan and Van Heuven, Walter J.B. (1999): Recognition of Cognates and Interlingual Homographs: The Neglected Role of Phonology. Journal of Memory and Language. 41:496-518.

Eco, Umberto (2001): Experiences in Translation. (Translated by Alastair McEweN) Toronto: University of Toronto Press. 
Fraser, Janet (1993): Public Accounts: Using Verbal Protocols to Investigate Community Translation. Applied Linguistics. 14(4):325-343.

Fraser, Janet (2000): The Broader View: How Freelance Translators Define Translation Competence. In: Christina SchäFFnER and Beverly AdAB, eds. Developing Translation Competence. Amsterdam: John Benjamins, 51-62.

Fusco, Maria Antonietta (1990): Quality in Conference Interpreting Between Cognate Languages: A Preliminary Approach to the Spanish-Italian Case. The Interpreters' Newsletter. 3:93-97.

Gerloff, Pamela (1988): From French to English: A Look at the Translation Process in Students, Bilinguals, and Professional Translators. Unpublished Ed.D. dissertation. Cambridge: Harvard University.

Gernsbacher, Morton Ann and Shlesinger, Miriam (1997): The Proposed Role of Suppression in Simultaneous Interpretation. Interpreting. 2(1):119-140.

GILE, Daniel (1995): Basic Concepts and Models for Interpreter and Translator Training. Amsterdam: John Benjamins.

Gollan, Tamar H., Forster, Kenneth and Frost, Ram (1997): Translation Priming With Different Scripts: Masked Priming with Cognates and Noncognates in HebrewEnglish Bilinguals. Journal of Experimental Psychology: Learning, Memory and Cognition. 23(5):1122-1139.

GoodRICH, Hubbard C. (1977): Distractor Efficiency in Foreign Language Testing. TESOL Quarterly. 11(1):69-78.

Hancin-Bhatt, Barbara and Nagy, William (1994): Lexical Transfer and Second Language Morphological Development. Applied Psycholinguistics. 15(3): 289-310.

JäÄskeläInen, Riitta (1989a): The Role of Reference Material in Professional vs. Non-Professional Translation: A Think-Aloud Protocol Study. In: Sonja Tirkkonen-Condit and Stephen Condit, eds. Empirical Studies in Translation and Linguistics. Joensuu: University of Joensuu, 175-200.

JäÄskeläInen, Riitta (1989b): Translation Assignment in Professional vs. Non-Professional Translation: A Think-Aloud Protocol Study. In: Candace SÉGuinot, ed. The Translation Process. Toronto: H.G. Publications, 87-98.

JäÄskeläınen, Riitta and Tirkkonen-Condit, Sonjia (1991): Automatised Processes in Professional vs. Non-Professional Translation: A Think-Aloud Protocol Study. In: Sonja TirkKONEN-CONDIT, ed. Empirical Research in Translation and Intercultural Studies. Tübingen: Narr, 89-109.

Jensen, Astrid (1999): Time Pressure in Translation. In: Gyde Hansen, ed. Probing the Process in Translation: Methods and Results, Copenhagen: Samfundslitteratur, 103-119.

Kroll, Judith F. and De Groot, Annette M. B. (1997): Lexical and Conceptual Memory in the Bilingual: Mapping Form to Meaning in Two Languages. In: Annette M. B. DE Groot and Judith F. Kroll, eds. Tutorials in Bilingualism: Psycholinguistic Perspectives. Mahwah: Lawrence Erlbaum, 169-199.

Kroll, Judith F. and Stewart, Erica (1994): Category Interference in Translation and Picture Naming: Evidence for Asymmetric Connections between Bilingual Memory Representations. Journal of Memory and Language. 33:149-174.

Krouglov, Alexandr (1996): Social and Cultural Differences. In: Cay Dollerup and Vibeke Appel, eds. Teaching Translation and Interpreting 3: New Horizons. Amsterdam: John Benjamins, 81-87.

Kussmaul, Paul (1995): Training the Translator. Amsterdam: John Benjamins.

Kussmaul, Paul and Tirkkonen-Condit, Sonja (1995): Think-Aloud Protocol Analysis in Translation Studies. TTR 8:177-199.

Livbjerg, Inge and Mees, Inger M. (1999): A Study of the Use of Dictionaries in Danish-English Translation. In: Gyde Hansen, ed. Probing the Process in Translation: Methods and Results. Copenhagen: Samfundslitteratur, 135-147. 
Meara, Paul (1993): The Bilingual Lexicon and the Teaching of Vocabulary. In: Robert Schreuder and Bert Weltens, eds. The Bilingual Lexicon, Amsterdam: John Benjamins, 279-297.

Murray, David J. (1986): Characteristics of Words Determining How Easily They Will Be Translated into a Second Language. Applied Psycholinguistics. 7:353-372.

Nagy, William E., García, Georgia Earnest, DurgunoĞLu, Aydin and Hancin-Bhatt, Barbara J. (1992): Cross-Language Transfer of Lexical Knowledge: Bilingual Students' Use of Cognates. In: Technical Report No. 558 [ERIC document ED 350 869].

Newmark, Peter (1996): Looking at English Words in Translation. In: Gunilla Anderman and Margaret Rogers, eds. Words, Words, Words: The Translator and the Language Learner. Clevedon: Multilingual Matters, 56-62.

Partington, Alan (1995): True Friends Are Hard to Find: A Machine-Assisted Investigation of False, True and Just Plain Unreliable "Friends." Perspectives: Studies in Translatology. 3(1):99-111.

Presas, Marisa (2000): Bilingual Competence and Translation Competence. In: Christina SchäfFner and Beverly AdAB, eds. Developing Translation Competence. Amsterdam: John Benjamins, 19-31.

RabadÁn, Rosa (1991): The Unit of Translation Revisited. In: Mildred L. Larson ed. Translation: Theory and Practice, Tension and Independence, New York: State University of New York at Binghamton, 38-48.

Rabassa, Gregory (1989): No Two Snowflakes Are Alike: Translation as Metaphor. In: John Biguenet and Rainer Schulte, eds. The Craft of Translation, Chicago: University of Chicago Press, 1-12.

Sabaté-Carrové, Mariona and ChesŇevar, Carlos Iván (1998): False Friends in EnglishSpanish Translations in Computer Science Literature. Perspectives: Studies in Translatology. 6(1):47-59.

Sánchez-Casas, Rosa, Davis, Christopher and García-Albea, José (1992): Bilingual Lexical Processing: Exploring the Cognate/Non-cognate Distinction. European Journal of Cognitive Psychology. 4(4):293-310.

Santos Maldonado, Carmen (1997): Lexical Processing in Uneven Bilinguals: An Exploration of Spanish-English Activation of Form and Meaning. Edinburgh Working Papers in Applied Linguistics. 8:76-97.

SÉGuinot, Candace (1990): Interpreting Errors in Translation. Meta. 35(1):68-73.

SÉGUINot, Candace (1997): Accounting for Variability in Translation. In: Joseph H. DANKs, Gregory M. Shreve, Stephen B. Fountain, and Michael K. McBeath, eds. Cognitive Processes in Translation and Interpreting. Thousand Oaks: Sage, 104-119.

Seleskovitch, Danica (1978): Language and Cognition. In: David Gerver and H. Wallace SinaIKo, eds. Language Interpretation and Communication. New York: Plenum, 333-341.

Shlesinger, Miriam (1992): Lexicalization in Translation: An Empirical Study of Students' Progress. In: Cay Dollerup and Anne LoddegaArd, eds. Teaching Translation and Interpreting: Training, Talent and Experience. Amsterdam: John Benjamins, 123-127.

Shlesinger, Miriam (2000): Strategic Allocation of Working Memory and Other Attentional Resources in Simultaneous Interpreting. Unpublished doctoral dissertation. Ramat Gan: Bar Ilan University.

TirkKonen-Condit, Sonja (1986): Text Type Markers and Translation Equivalence. In: Juliane House and Shoshana Blum-KulKa, eds. Interlingual and Intercultural Communication: Discourse and Cognition in Translation and Second Language Acquisition Studies. Tübingen: Narr, 95-113.

Tirkkonen-Condit, Sonja (1996): What Is in the Black Box?: Professionality in Translational Decisions in the Light of TAP Research. In: Angelika LaUer, Heidrun Gerzymisch-Arbogast, Johann HALLER and Erich STEINER, eds. Übersetzungswissenschaft im Umbruch. Tübingen: Narr, 251-257. 
Topalova, Antoanita (1996): False Friends in Translation Work: An Empirical Study. Perspectives: Studies in Translatology. 4(2):215-222.

Toury, Gideon (1992): "EVERYTHING HAS ITS PRICE”: An Alternative to Normative Conditioning in Translator Training. Interface: Journal of Applied Linguistics. 6(3):60-72.

Viaggio, Sergio (1991): Semantic and Communicative Translation: Two Approaches, One Method. In: Mildred L. Larson, ed. Translation: Theory and Practice, Tension and Independence. New York: State University of New York at Binghamton, 172-187.

Viberg, Åke (1999): The Polysemous Cognates Swedish gå and English go: Universal and Language-Specific Characteristics. Languages in Contrast. 2(1):87-114.

WALLERSTEIN, Immanuel (1996): Scholarly Concepts: Translation or Interpretation? In: Marilyn Gaddis Rose, ed. Translation Perspectives IX: Translation Horizons. New York: State University of New York at Binghamton, 87-106. 